\title{
Information on Domestic Staff Utilisation and Household Crimes
}

\author{
Frank M. Attah ${ }^{\mathrm{a}}$, A. M. Ogaboh Agba ${ }^{\mathrm{a},}$, Azu A. Ibiam ${ }^{\mathrm{a}}$, Phyllis K. Kaburise ${ }^{\mathrm{a}}$, Collins Kulo ${ }^{\mathrm{b}}$ \\ ${ }^{a}$ Department of Sociology, University of Calabar, Nigeria \\ ${ }^{b}$ University of Venda, Thohoyandou, South Africa
}

\begin{abstract}
Hiring of domestic staff and its effect on households' crime has been an issues of great concern in Nigeria. This study evaluates available information on domestic staff utilisation and crimes such as kidnapping, stealing and rape. Blocked opportunity theory and structural functionalism theory were adopted. Cross-sectional survey design was used while data was generated view questionnaire. A total sample of 330 respondents were selected from households in Southern Senatorial District of Cross River State, Nigeria. Information retrieved were coded and subjected to statistical analysis. Assessed information revealed a relationship between the hiring of domestic staff and household crimes (such as kidnapping, stealing and rape). It was recommended among others that house helps should be passably screened through proper employment procedures before they are employed as domestic staff.
\end{abstract}

(C) 2021 Author(s). All rights reserved.

Keywords: Domestic staff; household crime; kidnapping; stealing and rape.

\section{Introduction}

Most homes are predominantly occupied by house helps such as drivers, gatemen, cooks, cleaners, lesson teachers, gardeners among others. These staff are originally employed to render services based on specific and general house chores. According to ACE Private Risk Services (2015) families with busy schedules and substantial assets often employ domestic staff such as nanny, housekeeper, driver, chef or caretaker. Ironically, these families who have achieve great success in their professional lives, sometimes do not follow proper employment procedures before engaging domestic staff, thus exposing themselves to danger.

The institutionalization of house help and the increasing rate domestic crimes has over the years gain global attention. This is because a great number of families are now leaving house chores and domestic duties at the mercies of house helps and this is not without consequence. Again, as the society progresses from simple to complex, criminality and crime among house helps evolves and is spreading geometrically. According to Sutton (2009), one possible explanation for this phenomenon is that, house work is been exchanged for economic support and gains. Albanese (2001) argue that domestic crimes are products of impede opportunity and want of access to legitimate means for attaining goals. Chioma (2016) maintain that the cases of wicked domestic staff are on the increase and at an alarming rate. She advocated for the establishment of professional and certified board that will be in charge of procuring domestic staff for households.

In Nigeria, most household employers have either been killed, kidnapped, raped or property stolen by the house helps. Household crimes orchestrated by domestic staff has consumed many precious lives and rendered some homes and families incapacitated. The emergence of house help has brought nothing but untold family disaster and places the family line on the keg of gun powder. While the phenomenon continues to ravage many families in Nigeria in particular, there are lack of empirical studies that will provide concrete bases for policy formulation. This study is set

\footnotetext{
* Corresponding author.

E-mail address: xxxx@xxxxxx.edu (First Author)
} 
to bridge this knowledge gap by empirically establishing the links between the hiring of domestic staff and household crimes. Specifically, the study:

(i) Examines the extent to which the utilization of house helps results to kidnapping of employers;

(ii) Identify the relationship between domestic staff hiring and the rape of employers;

(iii) Investigate whether the use of domestic staff could lead to the stealing of employers' property.

\section{Literature Review}

Existing research shows the relationship between domestic staff utilisation and kidnapping (Agba, \& Agba, 2008; Chioma, 2016; Agba, \& Ushie, 2014; Agba \& Agba, 2008). Chioma (2016) posit that domestic staff who are not well taken care of by their employers, especially drivers who knows much of their boss routines are often tempted to kidnap their employers or their family members for a ransom. Fage and Alabi (2017) conceived kidnapping/fraudulent abduction for economic, political and religious gains. This further suggests that, poor welfare package for domestic staff could inform kidnapping of employers. Ugwuoke (2015) posit that the motives for domestic staff kidnapping their employers or their family members varied but essentially they can be subsumed under economic, political and social reasons. The economic reasons are a pointer that most domestic staff work as elephant and eat like an ant. This best explains why domestic staff whose monthly stipend is below poverty line endorse in kidnapping activities. Hazen and Horner (2007) conducted a similar research and observe that most domestic staff who knows their employers' secrete (yet less taken care off) may volunteer such information to criminals for socioeconomic gains. Bello and Jamilu (2017) argue that economic deprivation and desperation have planted the seeds of kidnapping in the very minds of domestic staff. Thus, economic gains and the quest for quick money accounts largely for the rising rate of kidnapping by domestic staff.

Studies revealed the nexus between house help and rape of employers. Eneji (2015) argue that, if house helps are occasionally given break to meet their love ones, the incident of domestic staff rapping their employers or members of their families will be reduce. Okon (2011) conducted a similar study and maintained that employers' rape is an expression of male sexuality, which threatens and intimidates women. In this regards, it is a violent crime that is only committed by male gender. Ugwuoke (2015) examined crimes in contemporary Nigeria and conclude that rape is a crime of violence because force is used in the process of its committal. Most domestic staff do not have time to leave their job premises to quench their sexual urge, so, they term to force either their employer's wife, or children to have a canal knowledge without their consents. Alieba (2005) in his study, affirmed that employers' rape entails an act done through direct violent and forceful sexual intercourse by a male to a female. Suggesting that female domestic staff could also rape their male employers.

Marshall and Robert (2008) observe that some domestic staff shoplift valuables or items from the premises of employers. Domestic staff stealing includes inventory shrinkage which entails business loss of goods from illegal activities. Most domestic staff steal the property their employer at any slight opportunity. Mieth, et al. (2006) carried out a research on some dubious domestic workers; and the findings revealed that some domestic staff would even pretend to be on joyriding only with intention to steal the car or property of their employers. ACE private risk services (2015) further elaborated that theft is one of the most common crimes committed by dishonest household employees, and the risk increases if they are meant to work without day-to-day supervision. Igbo (2007) and Samaha (2008) argue that the employers private and personal properties are no longer save in the very hands of staff who are under their pay rolls.

\section{Theoretical framework}

The theory of Blocked opportunity and structural functionalism was adopted for this study. The Blocked opportunity theory was propounded by Richard Cloward and Lloyd Ohlin in 1960. The theory holds that individuals commit crimes when the possibility of being caught is slim and from readily available illegitimate opportunities created in order to achieve cultural goals. According to Merton (1938) society is structured in such a way that it creates class distinction between the haves and the have not who are always under societal pressure to gain financial security. The domestic staff who by societal rating belongs to the lower class, in their quest for cultural goals attainment adopts 
illegitimate means such as kidnapping, rape and stealing of employers' properties. Igbo (2007) observe that access to legitimate means for the attainment of cultural goals and expectations is not equally distributed in society. He argues that access to illegitimate means is also not equally available to all. Cloward and Ohlin (1960) posit that crime results from the frustration of poor youths (including young domestic staff) whose aspirations for success are blocked. In a society where there is a disjunction between the culturally expected goals and means available for their attainment, deprived persons are more likely to commit crime.

Structural functionalism was developed in the 1930s through 1960s in the United States. Its proponents are Talcott Parsons, Kingsley Davis, Wilbert Moore and Robert Merton. The basic assumption is that individuals (both the domestic staff and employers) are inter-connected through socialization and learning in a social system (Parson, 1951). The theory holds that society consists of both the rich (employers) and the poor (house helps). They both interacts and are interdependent with one another with diverse roles and obligations to be perform each in order to achieve the overall function of the whole. These individuals are called social actors (Okokon, 2014). As a result of this social arrangement, the services of the domestic staff are highly needed in the homes of the rich for them to have a decent life. A home where ones return from work to meet a meal on the table, have someone that always open the gate, watch and iron clothes, drive the children to school, clean both rooms and compound among others. This theory therefore explained why the services of domestic staff are needed in many homes across the world.

\section{Methods}

The cross-sectional survey design was utilized for the study. The survey allows for the selection of respondents, and the administration of structured questionnaires (Ukwayi, Angioha \& Ojong-Ejoh, 2018; Angioha, Nwagboso, Ironbar, \& Ishie, 2018; Ukwayi, Angioha, \& Aniah, 2019; Agba, Nkpoyen, \& Ushie, 2010; Angioha, Enukoha, Agba, \& IKhizamah, 2020). The method enabled this study to examine respondents' knowledge, perception and attitude in relation to the hiring of domestic staff and household crimes. The study was carried out in Southern Senatorial District of Cross River State, Nigeria. The district comprised of Biase (10 political wards), Akamkpa (10 political wards), Odukpani (13 political wards), Calabar Municipality (10 political wards), Calabar South (12 political wards), Akpabuyo (10 political wards) and Bakasi (10 political wards). It is bounded in the West by Republic of Cameroon, in the North by Yakurr Local Government Area, and in the East by the Atlantic Ocean. The local governments are managed by Chairmen while councillors provide legislative support to the executives. Paramount rulers, clan heads and as well as chiefs help in the maintenance of peace and order. It people are described as mini virtue because of their many ethnics, linguistic and multi cultures. They are of the Bantu Stock who migrated from Central Africa. The Efiks, Efuts, Quas, Ejagham and Ekios are dominant cultural groups that occupied the area. The total population of the study area is 1,590, 200 people as estimated by National Bureau of Statistics (NBS, 2016). This research adopted purposive sampling techniques. It was used in selecting employers of domestic workers as well as domestic staff from the seven local government areas. The sample for the study therefore comprised of residents in selected from the district. The study used close-ended questionnaire that elicit demographic information and information on the key variables of the study. Data collected in this study were checked and responses were edited, coded and analysed using appropriate statistical methods. Frequency distribution, simple percentages and linear regression analytical procedure were employed.

\section{Findings}

\subsection{Hypothesis one}

This hypothesis states that there is no significant correlation between the utilization of domestic staff and kidnapping. The hypothesis was tested using linear regression analysis in determining the best linear correlation between the hiring of domestic staff and kidnapping. The outcome (presented in table 1) illustrates that the predictor variable (utilization of domestic staff) significantly predicted kidnapping activities, $\mathrm{F}(1,360)=6.505, \mathrm{P}<.005$. The correlation is positive and small (R.133). More importantly, they accounted for $1.5 \%$ of the variance in kidnapping activities. The data weight suggests that the utilization of domestic staff contributes significantly to the prediction of kidnapping among employers of house-helps $(\beta=.133, t=7.923, p<.05)$, the adjusted $R$ Squared value of .015 , indicate that 
$1.5 \%$ of the variance in kidnapping was explained by the model. Therefore, the statement that, there is no significant relationship between the utilization of domestic staff and kidnapping was rejected while upholding that the utilisation of domestic staff has significant correlates with the instances of kidnapping.

Table 1. Linear regression of the utilization of domestic staff and household crimes

\begin{tabular}{|c|c|c|c|c|c|}
\hline Variable & Mean & SD & \multicolumn{2}{|l|}{ r-value } & Sig. \\
\hline Utilization of domestic staff & 17.4420 & 2.558 & \multirow{2}{*}{\multicolumn{2}{|c|}{0.133}} & \multirow[t]{2}{*}{0.000} \\
\hline Kidnapping & 17.4420 & 1.808 & & & \\
\hline \multicolumn{6}{|l|}{ Model summary } \\
\hline Model & $\mathrm{R}$ & R Square & \multicolumn{2}{|c|}{ Adjusted R Squared } & $\begin{array}{l}\text { Sd. Error of the } \\
\text { Estimate }\end{array}$ \\
\hline 1 & 0.133 & 0.018 & \multicolumn{2}{|l|}{0.015} & 2.539 \\
\hline \multicolumn{6}{|l|}{ ANOVA } \\
\hline Model & Sum of Squares & Df & Mean Square & $\mathrm{F}$ & Sig. \\
\hline Regression & 41.947 & 1 & 332.473 & 6.505 & 0.011 \\
\hline Residual & 2321.555 & 360 & \multirow{2}{*}{\multicolumn{2}{|c|}{5.267}} & \\
\hline Total & 2363.503 & 361 & & & \\
\hline \multicolumn{6}{|l|}{ Regression coefficients } \\
\hline Model & B & Std. Error & Beta & $\mathrm{T}$ & Sig. \\
\hline Constant & \multirow{2}{*}{$\begin{array}{l}10.266 \\
0.188\end{array}$} & 1.296 & & 7.923 & 0.000 \\
\hline Kidnapping & & 0.074 & 0.133 & 2.550 & 0.011 \\
\hline
\end{tabular}

$\mathrm{F}(1,360)=6.505, \mathrm{P}<0.05$.

\subsection{Hypothesis two}

This hypothesis states that there is no significant correlation between the hiring of domestic staff and rape. The hypothesis was tested using linear regression analysis in determining the best linear correlation between the utilization of domestic staff and rape. The outcome (presented in table 2) illustrates that the predictor variable (utilization of domestic staff) significantly predicted rape occurrence, $\mathrm{F}(1,360)=29.521 ; \mathrm{P}<$. 005. The correlation is positive and moderate (R.159). More importantly, they accounted for $2.5 \%$ of the variance in rape occurrence among employers of domestic staff and their families. The data weights suggest that an increase in the utilization of domestic staff contribute significantly to the rape occurrence among employers of house-helps and their families $(\beta=.159, \mathrm{t}=$ $5.433, \mathrm{p}<.05$ ), the adjusted R Squared value of .025 , indicate that $2.5 \%$ of the variance in the rape occurrence was explained by the model. Therefore, the statement that, the utilization of domestic staff has no significant correlates with rape was rejected while upholding that the utilisation of domestic staff has significant correlates with the instances of rape.

Table 2. Linear regression of the hiring of domestic staff and rape

\begin{tabular}{lllll}
\hline Variable & Mean & SD & r-value & Sig. \\
\hline Utilization of domestic staff & 12.146 & 2.35686 & 0.159 & 0.000 \\
Rape occurrence & 13.55 & 3.01745 & & \\
\hline Model summary & & & & \\
\hline \multirow{2}{*}{ Model } & \multirow{2}{*}{$\mathrm{R}$} & \multirow{2}{*}{ R Square } & \multirow{2}{*}{ Adjusted R Squared } & $\begin{array}{l}\text { Sd. Error of the } \\
\text { Estimate }\end{array}$ \\
\hline 1 & 0.159 & 0.023 & 0.024 & 2.32784 \\
\hline
\end{tabular}




\begin{tabular}{llllll}
\hline ANOVA & \multicolumn{5}{l}{} \\
\hline Model & Sum of Squares & Df & Mean Square & F & Sig. \\
\hline Regression & 159.972 & 1 & 159.972 & 29.521 & 0.000 \\
$\begin{array}{l}\text { Residual } \\
\text { Total }\end{array}$ & 6155.825 & 360 & 5.419 & & \\
\hline \multicolumn{7}{l}{} & 361 & & & \\
\hline Regression coefficients & B & Std. Error & Beta & T & Sig. \\
\hline Model & 13.983 & 0.384 & & 36.459 & 0.000 \\
\hline Constant & 0.124 & 0.023 & 0.159 & 5.433 & 0.000 \\
Rape occurrence & & & & &
\end{tabular}

$\mathrm{F}(1,360)=29.521 ; \mathrm{P}<0.05$.

\subsection{Hypothesis three}

This hypothesis states that, the engagement of domestic staff does not significantly relate to stealing of employers' property. From Table 3, it revealed that the linear regression was conducted to determine the best linear relationship between utilization of domestic staff and stealing. Findings in Table 3 shows that the predictor variable (utilization of domestic servants) significantly predicted the rate of stealing. $\mathrm{F}(1,360) \mathrm{F}=5.311$ : $\mathrm{P}<0.05$ level of significance. Based on the result, the correlation is positive and moderate R.121. The data weight suggests that an increase in the utilization of domestic staff promote significantly the rate of stealing $\mathrm{B}=.135, \mathrm{t}=2.564, \mathrm{P}<0.05$ the adjusted $\mathrm{R}$ square value of .0214. Therefore, the statement that, the utilization of domestic staff has no significant correlates with rape was rejected while upholding that the utilisation of domestic staff has significant correlates with the instances of stealing.

Table 3. Linear regression of the utilization of domestic staff and stealing

\begin{tabular}{|c|c|c|c|c|c|}
\hline Variable & Mean & SD & \multicolumn{2}{|l|}{ r-value } & Sig. \\
\hline Utilization of domestic staff & 17.3124 & 2.381 & \multirow{2}{*}{\multicolumn{2}{|c|}{0.361}} & \multirow[t]{2}{*}{0.000} \\
\hline Rate of stealing & 62.1341 & 1.808 & & & \\
\hline \multicolumn{6}{|l|}{ Model summary } \\
\hline Model & $\mathrm{R}$ & R Square & \multicolumn{2}{|c|}{ Adjusted R Squared } & $\begin{array}{l}\text { Sd. Error of the } \\
\text { Estimate }\end{array}$ \\
\hline 1 & 0.121 & 0.039 & \multicolumn{2}{|l|}{0.0214} & 2.739 \\
\hline \multicolumn{6}{|l|}{ ANOVA } \\
\hline Model & Sum of Squares & Df & Mean Square & $\mathrm{F}$ & Sig. \\
\hline Regression & 51.835 & 1 & 321.562 & 5.311 & 0.012 \\
\hline Residual & 3341.663 & 360 & 4.306 & & \\
\hline Total & 2374.612 & 361 & & & \\
\hline \multicolumn{6}{|l|}{ Regression coefficients } \\
\hline Model & $\mathrm{B}$ & Std. Error & Beta & $\mathrm{T}$ & Sig. \\
\hline Constant & \multirow{2}{*}{$\begin{array}{l}11.354 \\
-135\end{array}$} & 1.261 & & 6.931 & 0.000 \\
\hline Stealing rate & & 0.065 & 0.143 & 2.654 & 0.011 \\
\hline
\end{tabular}

$\mathrm{F}(1,360) \mathrm{F}=5.311: \mathrm{P}<0.05$ 


\section{Discussion of findings}

Hypothesis one was tested using linear regression and the analytical illustration revealed that the calculated correlation-value (r) of 7.923 is higher than the critical correlation-value (r) of .015 at a significant level of 0.05 . The implication therefore is that the utilization of domestic staff statistically relates to the instances of kidnapping of employers. This result shows that domestic staff kidnap their employers for economic gains. This outcome however correlates with the reports of Chioma (2016); Fage and Alabi (2017); Bello and Jamilu (2017) who observe that most kidnappings are motivated by domestic staff who have full knowledge of their employers' daily routine. It suggests that domestic staff link information to criminal gangs for financial rewards. However, Fage and Alabi (2017) argue that in some instances domestic staff engages in this antisocial behaviour because of political and religious reasons.

Hypothesis two was tested using linear regression and the result of the analytical illustration revealed that the calculated correlation-value (r) of 5.433 is higher than the critical correlation-value (r) of .025 at a significant level of 0.05 . This result suggests that there is no significant relationship between the utilization of domestic staff and rape occurrence in Southern Senatorial District of Cross River State, Nigeria. This result shows that some domestic staff rape their employers or family members because of privilege information they have available to them. This outcome however correlates with the reports of Eneji (2015), Ugwuoke (2015), and Alieba (2005) who argue that most domestic staff have carnal knowledge of their employers and their family members through forceful measures. Okon (2011) deduce that employers rape is only committed by male domestic staff whereas this study contend that employers rape could either be committed by the male or female domestic staff.

Hypothesis three was tested using linear regression and the result of the analytical illustration revealed that the calculated correlation-value (r) of 5.311 is higher than the critical correlation-value (r) of 2.564 at a significant level of 0.05. This analysis revealed that there is a significant relationship between the utilization of domestic staff and stealing of employers' properties in Southern Senatorial District of Cross River State, Nigeria. It shows that domestic staff in order to satisfy their material needs and desires, steal the personal belongings of their employers. This outcome corroborates with the works of Mieth and Richard (2006), Marshall and Robert (2008), who posit that despite the good relationship that exists between some domestic staff and their employers many more still steal their properties to enrich themselves. Furthermore, ACE private risk services (2015) explain that the act of stealing employers' property increases mostly when the nature of domestic staff job does not involve day-to-day supervision by the employer.

\section{Conclusion and recommendations}

This This study evaluates available information on domestic staff utilisation and the occurrence of crimes such as kidnapping, stealing and rape in Southern Senatorial District of Cross River State, Nigeria. Outcome revealed a significant relationship between the hiring of domestic staff and household crimes (such as kidnapping, stealing and rape). The study concluded that families who hire the services of house-helps are more likely to suffer from crimes such as rape, kidnapping and theft. It was recommended among others that house helps should be screened through proper employment procedures before they are employed as domestic staff. Government should establish an agency for the training and recruitment of domestic workers in Nigeria.

\section{References}

ACE Private Risk Services (2015). ACE - Managing risk of employing domestic staff. Retrieved on March $12^{\text {th }} 2019$. From www.gulfshoreinsurance.com/wp-content/uploads/2015/11/ace-managing-risk-of-employingdomestic-staff-white -paper-2015-10-pdf.

Agba, A. M. O. Nkpoyen, f. \& Ushie, E. M. (2010),“Career development and employee commitment in industrial organizations in Calabar, Nigeria", American Journal of Scientific and Industrial Research, Vol. 1 Issue 2, pp. 105-114. 
Agba, A. M. O., Frank, M. A. \& Edem, E. (2015). Enhancing the operational effectiveness of cooperative organizations for sustainable job creation in Nigeria. International Journal of Public Administration and Management Research (IJPAMR), 2(5), 95-100.

Agba, A. M. O., Nwosu, U. W. \& Innah, D. E. (2015). Correlates between family and employees' work life in Nigeria: The need for proper integration. International Journal of Capacity Building in Education and Management (IJCBEM), 2(3), 25-42.

Agba, A. M. O., Ushie, E. M.; Ushie, M. A.; Bassey, A. O. \& Agba, M. S. (2009). Human development trend in Nigeria: The need for concrete implementation of seven the point agenda. Nigerian Journal of Social and Development Issues, 6(1), 15-28.

Agba, A. O. \& Ushie, E. M. (2014). Essential readings in social policy and programme. Calabar: University of Calabar Press.

Agba, A. O. \& Ushie, E. M. (2014). Principles and management of cooperative organizations. Calabar: University of Calabar Press.

Agba, M. S. \& Agba, A. M. O. (2008). Human resources management and millennium development goals: The nexus. SOPHIA: An African Journal of Philosophy and Public Affairs, 10(2), 59-63.

Albanese, J. S. (2001). Criminal Justice. Needham Heights Allyn\& Bacon.

Aliegba, E. T. (2005). Violent against women: its nature and manifestations. In Angya C. (ed) perspectives on violence.

Angioha, P. U., Enukoha, C. U., Agba, R. U., \& Ikhizamah, G. U. (2020). Information technology predictor variables and employee productivity in commercial banks. JINAV: Journal of Information and Visualization, 1(1), 4452. https://doi.org/10.35877/454RI.jinav2125

Angioha, P. U., Nwagboso, S. N., Ironbar, A. E. \& Ishie, E. U. (2018). Underemployment: A Sociological and Policy Analysis of Workers Well-Being in Hospitality Industry in Calabar, Cross River State, Nigeria. IOSR Journal of Humanities and Social Science (IOSR-JHSS), Volume 23, Issue 6, Ver. 5 (June. 2018) PP 57-66.

Bello, I. E. Jamilu, I. M. (2017). An analysis of the cause and consequences of kidnapping in Nigeria. African Research Review, 11(4). Doi:10.4314/afrev.

Bimbo, W.O. (4 $4^{\text {th }}$ June 2016). In Chioma G. Retrieved on the $27^{\text {th }}$ March, 2019. From www.Vanguardngr.com/2016/06/the-stranger-in your home.

Chioma, (4 $4^{\text {th }}$ June 2016). Retrieved on the $27^{\text {th }}$ March, 2019. Access from www.vanguardngr.com/2016/06/the stranger -in-your -home.

Cloward, R. \& Ohlin, L. E. (1960). Delinquency and opportunity: A theory of delinquent gangs. New York: The Free Press of Glencoe.

Eneji R.I. (2015). Social change and theoretical view of social problems. China: Universal academic services.

Fage, K. S. \& Alabi, D. O. (2017). Nigeria government and politics. Abuja: Basfa global concept Ltd.

Functionalism and Parsons (November 2, 1999). Retrieved June 10, 2019 from http://uregina.cal-gingrich/n2f99.

Hazen, J. M. \& Horner, J. (2007). Small arms, armed violence and insecurity in Nigeria. The Niger Delta in perspective. Geneva: Small arms survey.

Igbo, E. U. (2007). Introduction to criminology. Enugu: University of Nigeria press Ltd.

Lain C. \& Natasha S. (2008). Researching criminology. New York: Open University Press.

Lockwood, D. (1956). Some remarks on the social system. British Journal of Sociology, 7, 134-143. 
Marshall C. \& Robert M. F. (2008). Sociology of deviant behavior. United States of America: Wadsworth, Cenage learning.

Merton, R. (1938). Social structure and anomie. America sociological review, 3 (5), 10.2307/2084686.

Miethe T. Richard M. et al., (2006). Crime profiles: The anatomy of dangerous persons, places situations $\left(3^{\text {rd }} \mathrm{ed}\right)$, Los Angeles Roxbury.

National Population Commission of Nigeria (WEB), National Bureau Statistics (WEB), 2016.

Okokon, J. C. (2014). Sociological theory: A historic - analytical approach on man and society. Calabar: University of Calabar Press.

Okon, E. E. (2011). Religion and human rights education. Calabar: University of Calabar press.

Parsons, T. (1951). The social system. New York: Free Press.

Skidmore, W. (1979). Theoretical in sociology ( $2^{\text {nd }}$ ed). Cambridge: Cambridge University Press.

Sutton, P. W. (2009). Anthony Giddens Sociology $\left(6^{\text {th }}\right.$ ed). United States of America: polity press.

Ugwuoke C.U. (2005). Restitution of crime victims in Nigeria: A study of public perception in Enugu State. Ph.D thesis, Dept. of Sociology/ Anthropology University of Nigeria, Nuskka.

Ugwuoke, C. U. (2015). Criminology: Explaining crime in the Nigeria context. ( $2^{\text {nd }}$ ed). Enugu: University of Nigeria Press limited.

Ukwayi, J. K., Angioha, P. U. \& Aniah, E. A. (2019). Associate Factor of Trafficking in Women and Children in Calabar, Cross River State, Nigeria. European Journal of Political Science Studies 3 (1), 1-15

Ukwayi, J. K., Angioha, P. U. \& Ojong-Ejoh, M. U. (2018). Youth empowerment: A criminological approach for crime prevention and control in Cross River State, Nigeria. IOSR Journal of Humanities and Social Science (IOSR-JHSS), 22 (11), 73-81.

Ushie E. M., Agba, A. M., Agba, M. S. \& Chime, J. (2010). Leadership style and employees' intrinsic job satisfaction in the Cross River Newspaper Corporation, Calabar, Nigeria. International Journal of Development and Management Review, 5(1), 61-73. 